\title{
The Implementation of Thematic Electronic Smart Book at KB-TK Pertiwi Semarang
}

\author{
Sri Sularti Dewanti Handayani, Akaat Hasjiandito, Edi Waluyo \\ Universitas Negeri Semarang, Semarang, Indonesia \\ e-mail: akaat@mail.unnes.ac.id
}

\begin{abstract}
The purposes of this study were to describe the implementation of electronic smart book at KB-TK Pertiwi Semarang, and to determine the effectiveness of that book used in the learning activities. This study used an experimental research with one shot case study research design that gives treatment to the experimental class and measures the results of the treatment carried out through one sample t-test. The results of this study showed that the teacher could teach well in theme-based learning activities by using the electronic smart book. The teacher explained the material based on the smart book by developing the material in the classroom. The response from the teacher on this electronic smart book was good. Whereas from point of view of students or the effectiveness of this research showed that the existence of learning by using the electronic smart book could increase students' attention and having better focus. They could capture the material delivered by the teacher more clearly because the smart book are prepared in accordance with stage of child's development so that the learning outcomes of students could increase and meet predetermined criteria.
\end{abstract}

Keywords: electronic smart book, kb-tk, thematic

\section{INTRODUCTION}

In early childhood education, the implementation of learning should be based on themes. It is well-known as thematic learning. It is in accordance with Government Regulation No. 137 and 146 which stated that the learning in PAUD must use 10 (ten) basic themes, namely 1) myself; 2) environment outside of house; 3) animals; 4) plants; 5) profession; 6) transportation; 7) homeland; 8) universe; 9) recreation; and 10) natural occurrences. The teacher should develop each theme into a subtheme that will be carried out in one of academic year. Based on Wirawati's research (2013), she stated that thematic learning can develop children's independence.

Early childhood education is an educational training effort for children from birth to 6 years of age which is carried out through the provision of educational stimuli to help physical and spiritual growth and development so that children will have readiness for further education (The Law No. 20/2003, Article 1: 14). Santoso in Jawati (2013) stated that early childhood education is an education that can determine the shaping of a child's personality. The results of the similar research conducted by Faiqoh (2015), she stated that obtaining education services from early ages can increase the character of honesty, tolerance, and peace.

The implementation of learning in PAUD must be supported by adequate media so that the material can be delivered maximally to children. The need for media in learning is very compulsory because the child's thinking process starts from the concrete operation stage. It is a stage of thinking by presenting real objects in learning activities. Piaget (1950) in Sulistya (2012) stated that every student has their own way of interpreting and adapting to their environment. The results of the neurology 
study presented by Osborn, White and Bloom in Apriana (2009) explained that the cognitive development in early childhood has reached $50 \%$ when the child is 4 years old, $80 \%$ when in 8 years old, and even $100 \%$ when in 18 years old.

In the reality of learning in kindergarten institutions, especially in KB-TK Pertiwi Semarang, there are still many teachers who use worksheets in their daily activities. This learning gives bad impact for children. They feel bored in learning and many of them do not pay attention to the teacher when delivering material. As a professional teacher, he/ she needs to do innovation in learning. One of which is utilizing information and communication technology like using the electronic smart book in learning activities. One of the processes carried out in learning in kindergarten is the existence of footing activities before playing. In this process, the teacher gives an overview of the material before being presented and provides concept reinforcement to students. To support learning and master the concept easier to be understood by the children, the teacher needs to use interesting media like electronic smart book as an alternative one.

At the time being, many learning resources in the form of book have changed from the text book to electronic book or often referred to as smart books. The results of the study presented by Restiyowati (2012) stated that the existence of smart books can increase the interaction between educators and students. Currently, the development of smart books has changed a lot. One of which is made more interactive by presenting various media in it such as animation and videos. The results of research conducted by Kurniawati (2011) stated that smart books deserve to be used in learning activities. Other research results also expalined that smart books can be used as learning resources for students (Rachmawati, 2010).

Electronic smart book is a textbook converted into digital format. It can also be interpreted as learning environments that have some applications to support multimedia databases of instructional resources that store some multimedia presentations on topics in a book (Restiyowati, 2012). James (2003) explained that a smart book contains digital information consisting of text, graphics, video, animation, sound and it is combined into one package. Besides containing some materials, smart book also contains an explanation of how to use and there are additional explanations on certain materials. Through the existence of electronic smart book, hopefully it would make easier for educators in delivering materials better and more concrete, as well as facilitate the students in learning activities. The purposes of this study were to describe the implementation of electronic smart book at KB-TK Pertiwi Semarang, and to determine the effectiveness of that books used in the learning activities.

\section{RESEARCH METHOD}

The research approach used in this study was an experimental method by using a one shot case study design. It gives the learning treatment by using an electronic smart book then measuring the learning outcomes of students with standard scales made by researcher. The design of this study is described as follows:

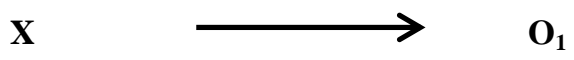

Figure 1. Research Design

Based on the picture, this study can be described as follows: the research is carried out by examining the learning outcomes of students compared with the standard scales by using t-test. $\mathrm{O}_{1}$ is a posttest and $\mathrm{X}$ indicates the treatment of learning by using electronic smart book. This learning can be said as an effective learning if the average score of posttest is higher than the standard scales determined by the researcher.

\section{RESULTS AND DISCUSSION}

\subsection{Research Results}

\subsubsection{Implementation of Thematic Electronic Smart Book in KB-TK Pertiwi Semarang}

Based on the results of observation, it obtained various results that can be used in developing electronic smart book to support cognitive development aspect of early childhood. The results of the observations can be explained as follows:

\section{a) Analysis Stage}

\section{(1) Competence Analysis}

Early childhood is an individual who has rapid growth and development process. Even, it is a developmental leap because early age can be said as the golden age which means that is a very valuable age compared to following ages. This age is a 
unique phase of life. Based on Regulation of the Minister No. 58 year of 2009, the achieving stage of 5-6 years children development are able to:

a. Classify objects based on their function.

b. Demonstrate some explorative and creative activities. For example, what happens when water is shed.

c. Arrange planning some activities that want to be carried out.

d. Know the causality in environment. For examples, the wind blows and causes the leaves move. Then, water can cause something to get wet.

e. Determine the initiative in choosing game themes like their saying "let's play pretending a bird".

f. Solve some simple problems in daily life.

\section{(2) Analysis of Student Characteristics}

Children, in their early ages, have extraordinary learning abilities. Especially in first early childhood. The children's desire to learn makes them active and explorative. They will reach their golden ages when they begin to be sensitive to receiving various stimuli called sensitive period. Children have different sensitive period depending on the rate of growth and development of children individually. In this ages, they will have maturity of physical and psychological function which is ready to respond to the stimulation provided by the environment (Rukiyah, 2013). Children learn with all five senses in order to understand something and they will move on to learn other things in a short time.

Children's way of learning will develop as they get older. Broadly speaking, Laily (2005) stated that the children aged 4-6 years should have better language skills. When they are able to communicate well, they will immediately do learning process by asking everything again and again with what they see. At this time, the cognitive aspect is growing rapidly and the desire to learn is higher. Finally, children learn something through asking and communicating.

\section{(3) Instructional Analysis}

Learning in PAUD is well-known as learning by playing. When playing, they are actually learning. According to Montessori in Hidayati (2014), when children are playing, they will absorb everything that happens in their surroundings. Children who play actually have various new things around them. This absorption process is what Montessori called as learning activities.

It's very important for parents and teachers in choosing and determining the type of media/games which are suitable for the children's development. The choosing and determining media/games are exactly the same as important as choosing a subject matter by the teacher for the development of students. It is a compulsory to be done so that the educational values in each game can be captured easily and pleasantly by children. If the type of game is not in accordance with the children's development, they will do playing only. No learning at all. Even it will have a negative impact on shaping their characteristics and intelligence. Conversely, the appropriate games will develop certain aspects of intelligence. They will learn something by playing completely.

The core of learning by playing is prioritizing learning rather than playing. Playing is only a means, not as a final destination. The games can be varied in many form whether using tools/ equipment or not. The most important thing is learning to master new things. Interactive slides of PowerPoint can be used as a learning media to develop children's cognitive aspect.

\section{b) Design Stage}

The design of the electronic smart book is adapted to the character of children. The media developed in this study is a kind of electronic book. The layout of electronic book is made more interesting and interactive completed with buttons and white space. The layout consists of header and content. In the header section, there is the title of the material. While in the content section, it contains materials. Layouts can be changed/ created according to learning needs.

The interactive CDs not only contain some materials but also quizzes or exercises to determine the level of cognitive development of early childhood after learning the material in the electronic smart book.

\section{c) Development Stage}

This smart book is created by using a computer application. That is a combination between Microsoft Office PowerPoint and Adobe Acrobat Reader Pro XI. The smart book contains some materials delivered to early childhood in the form of 
themes and sub themes completed by pictures, videos and some exercises or quizzes.

After being developed, the electronic smart book was used by teachers in teaching and learning activities in the kindergarten. The target institutions were KB-TK Pertiwi 45 Kalisegoro, precisely in TK $B$ because the age of children has reached 5-6 years where the child has reached a stage of development much better to receive material in the form of electronic smart book.

Teachers as educators in delivering learning materials in the kindergarten are used to using various media especially two-dimensional media like pictures. Along with the media, the teacher gives an explanation of the material that has been arranged in accordance with the themes.

This research provides alternative media that can be used by teachers in learning activities. The media is called thematic electronic smart book.

\subsubsection{Effectiveness of Thematic Electronic Smart Book in KB-TK Pertiwi Semarang}

\section{a. Improvement of Learning Outcomes}

The average learning outcomes of students after participating in learning by using electronic smart book especially for cognitive aspects was 93.13. While for main maze activities was 91.25. To determine the success of learning by using that book, it's used one sample t-test. The hypothesis are:

$\mathrm{H}_{\mathrm{o}}$ : the average learning outcomes of students are less than 80

Ha: the average learning outcomes of students are more than 80

The results of student learning outcomes analysis are shown in the following tables:

Table 1. One sample statistics

\begin{tabular}{llll}
\hline & $\mathbf{N}$ & Mean & $\begin{array}{l}\text { Std. } \\
\text { Deviation }\end{array}$ \\
\hline Value & 32 & 93,1250 & 20.38936 \\
\hline
\end{tabular}

Table 2. Analysis of Student Learning Outcomes

\begin{tabular}{lllll}
\hline & \multicolumn{4}{l}{ Test Value $=\mathbf{8 0}$} \\
\cline { 2 - 5 } & $\mathrm{T}$ & $\mathrm{df}$ & $\begin{array}{l}\text { Sig } \\
\text { tailed }\end{array}$ & $\begin{array}{l}\text { Mean } \\
\text { difference }\end{array}$ \\
Value & 3,641 & 31 &, 001 & 13,12500 \\
\hline
\end{tabular}

Based on the results of the analysis, it showed that the value of $\operatorname{sig}(0.001)$ is less than 0.05 , so $\mathrm{H}_{\mathrm{o}}$ is rejected and $\mathrm{Ha}$ is accepted. It means that the average learning outcomes of students is more than 80. It gained 93.13, which means that learning by using electronic smart book can improve student learning outcomes.

\section{b) Implementation of Electronic Smart Book}

After learning process was done, the teacher should fill out a questionnaire to find out the practicality level of the electronic smart book. Based on the results of the analysis of the teacher's answers, it showed that the use of electronic smart book learning is practical and effective to be used. This is based on the results of the analysis of the implementation instruments which were presented in the following table:

Table 3. Implementation of Learning

\begin{tabular}{|c|c|c|c|}
\hline No & Aspects & $\%$ & Criteria \\
\hline 1 & $\begin{array}{l}\text { Clarity of } \\
\text { instructions }\end{array}$ & 100 & Well Done \\
\hline 2 & $\begin{array}{l}\text { Achievement of } \\
\text { competence }\end{array}$ & 87,5 & Well Done \\
\hline 3 & $\begin{array}{l}\text { Children's } \\
\text { responses }\end{array}$ & 86,7 & Well Done \\
\hline 4 & $\begin{array}{l}\text { Level } \\
\text { convenience }\end{array}$ & 100 & Well Done \\
\hline 5 & Adequacy of time & 80 & Well Done \\
\hline
\end{tabular}

The use of electronic smart book has a significant influence in learning activities. The focus and attention of students in learning increased significantly. It has good impact on the achievement of students. The response of teachers on that book was also good and feels helped by the media from what is commonly used. Some teachers suggested that it's necessary to have some facilities such as tabs or other electronic media.

\subsection{Discussion}

The learning process in PAUD must meet with children's development. Education programs must be adapted to children. It's big mistake if children have to adjust to the education programs (Bradekamp in Rukiyah, 1999). Thematic education or well-known as theme-based learning is very appropriate with children because they learn something gradually and regularly. Children in general are active learners and 
have high level of curiosity. PAUD experts believe that playing is the best way for early childhood learning because children will get direct experiences (learning by playing). Therefore, in this study, this electronic smart book is developed in accordance with the stages of child's development.

The implementation of learning by using the electronic smart book has good impact on students in learning activities. This study showed that students can be more focused and pay attention to the material presented by the teacher. It is in line with a research conducted by Hasjiandito (2016) which stated that learning by using electronic media can affect the learning achievement of students. Moreover, currently, tablet computers like iPad and Android Pad equipped with high resolution and many tools make them very popular in this era. Compared to textbooks, e-books are more accessible and more flexible and contain various elements of objects such as texts, images, animation, and sounds (Woody et al. 2010).

Viewed from the teacher's point of view, learning by using electronic smart book helps the teachers in conveying the abstract concepts to be more concrete so that the material is easier for students to understand. Zaman (2010) explained that through learning media, information can be received by students is $75 \%$ through sight, $13 \%$ through hearing, $6 \%$ through touch, and $6 \%$ through smell. Furthermore, a teacher when conveying information to early childhood must use media so that the information can be received or absorbed by the child well. At the end, they are expected to have behavioral changes in terms of abilities, knowledge, attitudes and skills (Zaman, 2010).

The function of learning media for early childhood is definitely important because the development of children at this age is time to think concretely. This implies that the use of media as a message information for early childhood. Zaman (2010) stated that a teacher when conveying information to early childhood must use media so that the information can be received or absorbed by the child well. At the end, they are expected to have behavioral changes in terms of abilities, knowledge, attitudes and skills.

The choice of learning media is not a simple matter although it does not need to be considered as complicated one. It indicates that the teacher need knowledge and skills to choose media appropriately so that the decisions are made in accordance with existing needs. Basically the consideration of choosing media is very simple whether it can meet the needs and achieve the goals or not. Mc. Connel in Sadiman (1993) stated "if medium fits, use it!". Besides that, several factors need to be considered, for example: learning objectives, student characteristics or goals, type of learning stimuli (audio, visual, motion/movement, and so on), environmental conditions, local conditions and the extent of the range that need to be served. These factors must ultimately be converted into election decision norms or criteria.

Many studies have been conducted to formulate how to develop/utilize technology, especially e-books that are directed to learning. Woody et al. (2010) suggested that the development of e-books must contain more interesting content than textbooks. Children usually want to interact directly with e-books because it can be modified so that they can build their own knowledge (Bierman et al, 2010).

When viewed in terms of effectiveness, the electronic smart book can increase the focus of students' attention because it is developed and implemented based on the stages of child's development. It is in accordance with what was conveyed by Bradekamp (in Rukiyah, 1999) that in learning in PAUD, the program developed must be in accordance with the stage of child's development. It's a big mistake if the children adjust the programs.

The electronic smart book is developed according to the characteristics of children. Some characteristics of interactive media for PAUD (Haryanti, 2012) are the background chosen is appropriate with the theme because the learning model in PAUD is thematic. In layout settings, the title is on top. The material is in the middle. The main navigation is in bottom. The appearance of additional navigation can adjust freely (can be in the left, right, top and bottom). It also use bright colors, gradations and harmonization of colors that are comfortable in the eyes. Besides that, the color combinations must also be eye-catching. The form of font used basic letters, sharp, without thick and thin variations, having good contrast with the background, softly no flashy, and using lower case letters. The navigation tools used interesting symbols and describe the function of the button. The purpose of this research writing is to develop a conceptual model of interactive learning media intended for early childhood especially the theme of transportation tools that can be used for cognitive development aspect of early childhood. 


\section{CONCLUSION}

Based on the results of the research on the implementation of electronic smart book in KB-TK Pertiwi, it can be concluded that:

1. The implementation of learning by using electronic smart book carried out by teachers could be done well and got a positive responses from the teachers.

The use of electronic smart book was effective in learning. It could increase the students' attention because the material presented became more concrete so that the learning outcomes of students could increase significantly.

\section{REFERENCES}

[1] Arikunto, Suharsimi. (2010). Prosedur Penelitian Suatu Pendekatan Praktek. Jakarta: Rineke Cipta.

[2] Apriana, Rista (2009). Hubungan Pendidikan Anak Usia Dini dengan Perkembangan Kognitif Anak Usia Pra Sekolah di Kelurahan Tinjomoyo Kecamatan Banyumanik Semarang. Semarang: Program Studi Ilmu Keperawatan, Fakultas Ilmu Kedokteran Undip.

[3] Bierman, J., Ortega, L., \& Rupp-Serrano, K. (2010). E-book usage in pure and applied sciences. Science \& Technology Libraries, 29(1-2), 69-91.

[4] Faiqoh, N. (2015). Implementasi Pendidikan Berbasis Multikultural Sebagai Upaya Penguatan Nilai Karakter Kejujuran, Toleransi, Dan Cinta Damai Pada Anak Usia Dini Di Kiddy Care, Kota Tegal. BELIA: Early Childhood Education Papers, 4(2). Retrieved from

http://journal.unnes.ac.id/sju/index.php/belia/art icle/view/7541

[5] Haryanti, Dwi. 2012. Karakteristik Tampilan Mobile Learning PAUD. Disampaikan dalam Workshop Pengembangan Mobile Learning PAUD di Agas Solo.

[6] Hasjiandito, Akaat. (2015). Pengembangan Model Pembelajaran Blended Learning Berbasis Proyek pada Mata Kuliah Media Pembelajaran. Tesis. Semarang: PPs Universitas Negeri Semarang

[7] James, Ohene-Djan. (2003). Personalising Electronic Books. Journal of Digital Information, Vol. 3 No (4).
[8] Jawati, Ramaikis. (2013). Peningkatan Kemampaun Kognitif Anak melalui Permainan Ludo Geometri di Paud Habibul Ummi II. Jurnal Spektrum PLS Vol. 1 No (1) April.

[9] Kurniawati, Diyah. (2011). Pengembangan Ebook Interaktif. Skripsi. Surabaya: Universitas Negeri Surabaya.

[10] Restiyowati, Illa dan Sanjaya, I.G.M (2012). Pengembangan E-book Interaktif pada Materi Kimia Semester Genap. Unesa Journal of Chemical Education. Vol. 1 No (1) pp 130-135 June.

[11] Rusman. (2012). Model-model Pembelajaran. Depok: PT Rajagrafindo Persada.

[12] Rachmawati, Kurnia. (2010). Pengembangan Ebook Interaktif pada Materi Pokok Asam Basa. Skripsi. Surabaya: Universitas Negeri Surabaya.

[13] Rukiyah. (2013). Pembelajaran Sains untuk Anak Usia Dini Pengenalan Lingkungan Alam Sekitar sebagai Sumber Belajar.

[14] Sadiman, Arief S. 1993. Media Pendidikan: Pengertian, Pengembangan dan Pemanfaatannya. Jakarta: Pustekkom Dikbud clan PT. Raja Grafindo Persada

[15] Sugiyono. 2010. Metode Penelitian Pendidikan: Pendekatan Kuantitatif, Kualitatif, dan R\&D. Bandung: Alfabeta.

[16] Sulistya, Wardani Nanik. (2012). Pengaruh Pendidikan Karakter pada Pembelajaran Tematik terhadap Hasil Belajar Siswa. Disajikan dalam Seminar Nasional Pengembangan Pendidikan.

[17] Sukayati. (2004). Pembelajaran Tematik di SD merupakan Terapan dari Pembelajaran Terpadu. Yogyakarta.

[18] Suryosubroto. (2009). Proses Belajar Mengajar di Sekolah. Jakarta: PT. Rineke Cipta.

[19] Trianto. (2007). Model-model Pembelajaran Inovatif Berorientasi Konstruktivistik. Jakarta: Prestasi Pustaka.

[20] Wirawati, T., \& Syukri, M. (2013). Analisis Pelaksanaan Pembelajaran Tematik dalam Mengembangkan Kemandirian Pada Anak Di Tk Islam Al-Kautsar. Jurnal Pendidikan dan Pembelajaran, 2(1).

[21] Woody, W. D., Daniel, D. B., \& Baker, C. A. (2010). E-books or textbooks: Students prefer textbooks. Computers \& Education, 55(3), 945948.

[22] Zaman, Badru. (2010). Bahan Ajar Pendidikan dan Profesi Guru, Media. 